Jadwiga GRABDA

Parasitology

\title{
PARASITIC FAUNA OF GARFISH BELONE BELONE (L.) FROM THE POMERANIAN BAY (SOUTHERN BALTIC) AND ITS ORIGIN
}

\author{
PARAZYTOFAUNA BELONY BELONE BELONE (L.) \\ Z ZATOKI POMORSKIEJ POLUDNIOWEGO BALTYKU \\ I JEJ POCHODZENIE
}

\author{
Institute of Ichthy ology
}

\begin{abstract}
Parasitic fauna of the Pomeranian Bay garfish was examined and found to consist of 6 species. North Atlantic and Baltic species are distinguished. The question of garfish spawning migrations to the Southern Baltic is discussed.
\end{abstract}

\section{INTRODUCTION}

The garfish, a migratory pelagic species, occurs in waters surrounding Europe and North Africa. Its presence has been recorded from the North-West Atlantic, North Sea, English Channel, Mediterranean, Adriatic, and Black Seas.

Periodically, the species appears in the coastal waters of the Baltic Sea where it spawns. According to Jensen (1937), the garfish occurs in the Skagerrak and northern Kattegat in April-May and enters the Belt Sea in May and June, from where it probably proceeds farther into the Baltic. In the Pomeranian and Puck Bays, the agreas of garfish spawning grounds, the species is fished on from May-June through October, after which period it disappears from the inshore zone of the Southern Baltic and its fate during the winter remains unknown. In the eastern and northern parts of the Baltic the garfish is very rare but sporadically observed even off Finland (Fagerholm, 1976). 
The knowledge on biology of the species as well as its parasitic fauna in the Polish waters is far from complete. Reproduction and development of the Puck Bay garfish was studied by Demel $(1937,1948)$ who found the presence of spawning grounds and juveniles of the species in the Bay. For these reasons Demel considers garfish a native species for the Polish Baltic waters. Demel's studies on the Puck Bay garfish were continued by Kompowski (1965 a; 1965 b) who studied the age structure, growth, fecundity, and food composition of the population.

Studies on the garfish parasitic fauna are also incomplete; they have usually been fortuitious and based on a low number of fishes examined. They are purely faunistic investigations. Until 1968 (Grabda, 1971) only one species, the acanthocephalan Pomphorhynchus laevis, had been recorded in the Polish waters, a single individual being found in the Gulf of Gdańsk garfish. Rokicki (1975) who examined 2 fish individuals only, caught in the Gulf of Gdańsk as well, found a single nematode and a single acanthocephalan; he gave no further particulars.

A more comprehensive review of the garfish parasites was presented by Rynkiewicz (1970) who examined 150 individuals caught in the Puck Bay in 1966 and 1967 and found 7 following parasitic species occurring commonly in many fish species in Poland's fresh and brackish waters: Diplostomum spathaceum (Rud., 1819), Tylodelphys sp., Scolex pleuronectis Müller, 1788, Contracaecum aduncum (Rud., 1802), Cucullanus truttae (Fabricius, 1794), Pomphorhynchus laevis (Zoega in Müller, 1966), and Neoechinorhynchus rutili (Müller, 1780).

Additionally, a contribution by Prost (1967) should be mentioned here; she examined 176 Puck Bay garfish individuals in order to compare their monogenean invasion with that occurring in the Mediterranean and Adriatic garfish, and failed to find any parasites of this group in the Baltic.

The knowledge of garfish parasites in waters od Poland's neighbours is by no means more advanced. Engelbrecht (1958) examined 7 garfish individuals from the Greifswalder Bodden and Kleiner Haff and found only a single larva of Terranova decipiens and Cercaria sp. However, he did not discuss the parasite invasion in the garfish in more detail. In the eastern Baltic, off Kaliningrad, the absence of parasites in the garfish was stated (Wegener, 1909). It has been only recently that Fagerholm (1976) published his observations (supplemented by his personal communication) on the garfish from the Finnish brackish waters (northern Aland, Geta). One individual out of 5 examined by Fagerholm contained 5 larvae of Anisakis.

As shown by this short review, the Polish studies on the garfish and its parasites were concentrated in the Gulf of Gdańsk and Puck Bay, whereas there are no data whatsoever from the Pomeranian Bay. To fill this gap, studies on the garfish parasites in this part of the Baltic have been undertaken. 


\section{MATERIAL AND METHODS}

The fishes to be examined were caught in the coastal waters of the Pomerianian Bay by the fishermen belonging to the "Belona" Fishermen's Cooperative in Dziwnów.

In September and October 1978, 34 and 26 individuals, respectively, were examined. In June and September 1979, the respective numbers of individuals examined were 15 and 11, while in June 1980, 17 individuals were studied. A total of 103 fish individuals measuring (1.t.) 57-78 cm and weighing 280-680 g was subject to examination.

The abdominal cavity, digestive tract, and muscles were examined.

\section{RESULTS AND DISCUSSION}

The materials studied revealed the presence of 6 parasitic species. The abdominal cavity was found to harbour larvae of the cestode Lacistorhynchus tenuis (van Beneden, 1858) (Tetrarhynchida: Lacistorhynchidae), stage 3 larvae of two nematode species: Anisakis simplex (Rud., 1809) and Thynnascaris adunca (Rud., 1802), while three acanthocephalan species were found in the intestine: Neoechinorhynchus rutili (Müller, 1780), Pomphorhynchus laevis (Zoega in Müller, 1776), and Echinorhynchus gadi Zoega in Müller, 1776.

All the species found were represented by small numbers of individuals or as single specimens. Table 1 summarises numbers of individuals found as well as data on the invasion incidence and intensity.

The parasites found can be divided into two groups. One group comprises the Atlantic species: Lacistorhynchus tenuis and Anisakis simplex, for the first time found in the garfish from the Polish part of the Baltic Sea. These are marine species that do not encounter a full spectrum of hosts necessary to complete their life cycle, being thus unable to reproduce in the Southern Baltic. The other group consists of the Baltic species: Thynnascaris adunca, Neoechinorhynchus rutili, Pomphorhynchus laevis, and Echinorhynchus gadi. These are brackish and fresh water forms, common in the Baltic inshore zone and, besides garfish, are found also in many other fish species. The parasites belonging to this group encounter all their hosts in the Southern Baltic. The garfish becomes infested during spawning.

According to Kompowski (1965 a,b), the garfish is known to spawn intermittently and to feed until the very beginning of the spawning and also in between its stages. The garfish food consists of fish, mainly Ammodytes tobianus L. and Hyperoplus lanceolatus (de Sauvage), and invertebrates such as Gammarus sp., Pontoporeia sp., as well as insects. All the organisms mentioned are intermediate hosts for the acanthocephalans listed above.

The $L$. tenuis plerocercus larvae live encysted on various organs in the abdominal cavity (Fig. 1-3) of the teleost fish. They have been found both in the garfish and in many other fish species present in waters surrounding Europe, off the Atlantic coast of 


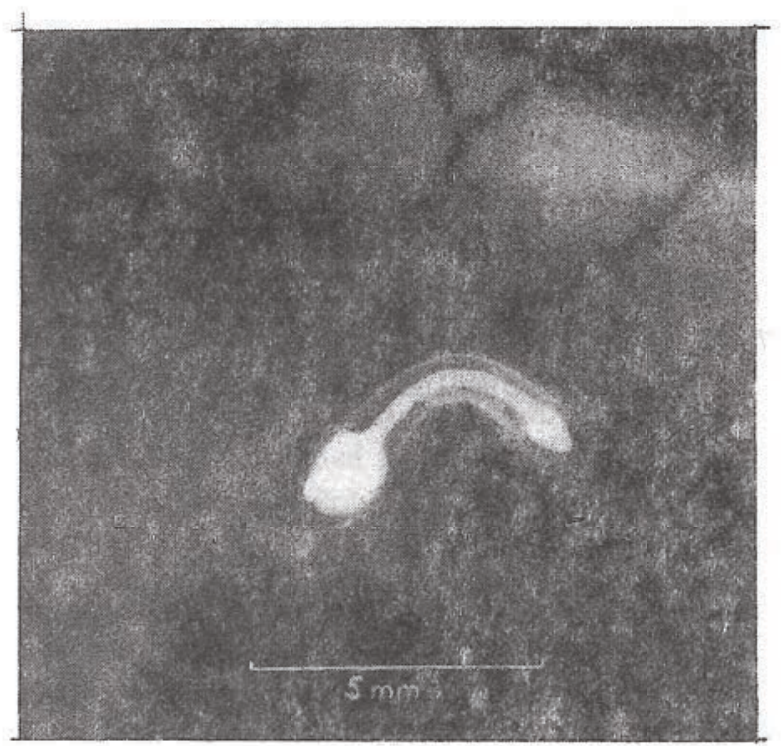

Fig. 1. Plerocercus of Lacistorhynchus tenuis on the liver of garfish.

Phot. I. Korzyńska

North America and in the Pacific waters of New Zealand. Many authors hav recorded them in the garfish off France, Denmark, Belgium, Sweden, and also in German Democratic Republic (Greifswalder Bodden), where the species appears to spawn. Adult cestodes were found in the spiral valve of sharks (Selachii) such as Galeus canis Rondelet, Mustelus hinnulus (Blainville), M. canis (Mitchill), Acanthias acanthias (Rondelet) and others. The main definite host of $L$. tenuis in the European waters is $G$. canis, the parasite being frequently noted in the fishes caught off France and Belgium. An extensive list of host species has been compiled by Dollfus (1942).

The presence of $L$. tenuis in New Zealand fishes is noted by Robinson (1959).

The sharks are absent from the Baltic, thus the cestode has no possibility to complete its life cycle; the parasite may be accidentally carried into the Baltic when living in a teleost fish as is the case with the garfish.

Undoubtedly, the garfish becomes infested with $L$. tenuis on remote North Sea feeding grounds and carries the parasites into the Baltic during spawning. The parasite is a biological tag evidencing extensive fish migrations in search for appropriate spawning grounds. The $L$. tenuis larvae were treated as biological indicators by MacKenzie (1976) in his attempt to explain herring migrations from Bloden in the North Sea to Minch (West off Scotland).

Similar is the case of the Anisakis simplex larvae. The nematode is common in numerous marine fish species all over the world. This is the first record of the species in the garfish from the Polish part of the Baltic. The nematode is undoubtedly an alien element for the Baltic fauna as its first intermediate hosts, the Euphausiacea, are absent 


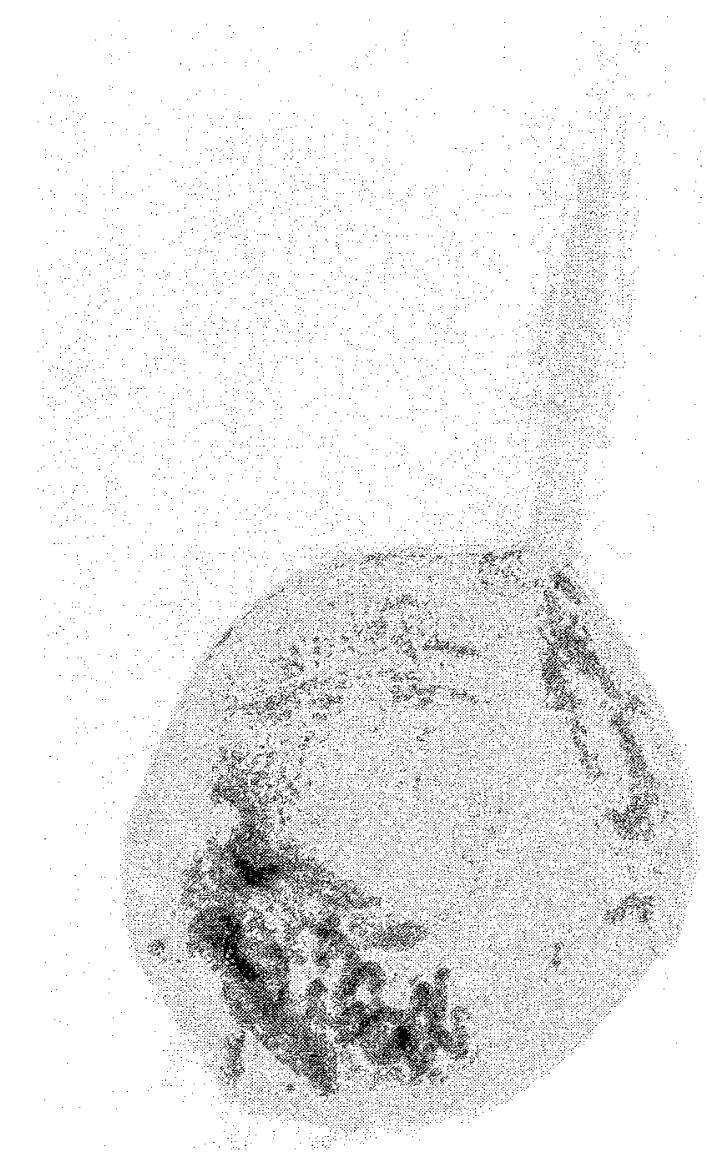

Fig. 2. Lacistorhynchus tenuis larva inside the blastocystis.

Phot. S.L. Kazubski

here, and its definite hosts - porpoises and seals - are so extremely rare in the Baltic that they could not possibly play the part of permanent components of this parasite's life cycle.

So far, the A. simplex larvae have been recorded from the western herring, periodically appearing in the Southern Baltic to spawn (Grabda, 1974), while the native Baltic herring are Anisakis-free. An Anisakis invasion was also observed in the Baltic cod (Grabda, 1976); that should be, however, regarded as a secondary invasion brought about by cod feeding on herring on the latter's spawning grounds. The recently observed invasion in the garfish seems to be a primary one, as is the case with western herring, and contracted in the North Sea feeding grounds.

Off the Polish coast, the garfish feeds mainly on the fishes Ammodytes tobianus and Hyperoplus lanceolatus; the Pomeranian Bay representatives of those species have not 


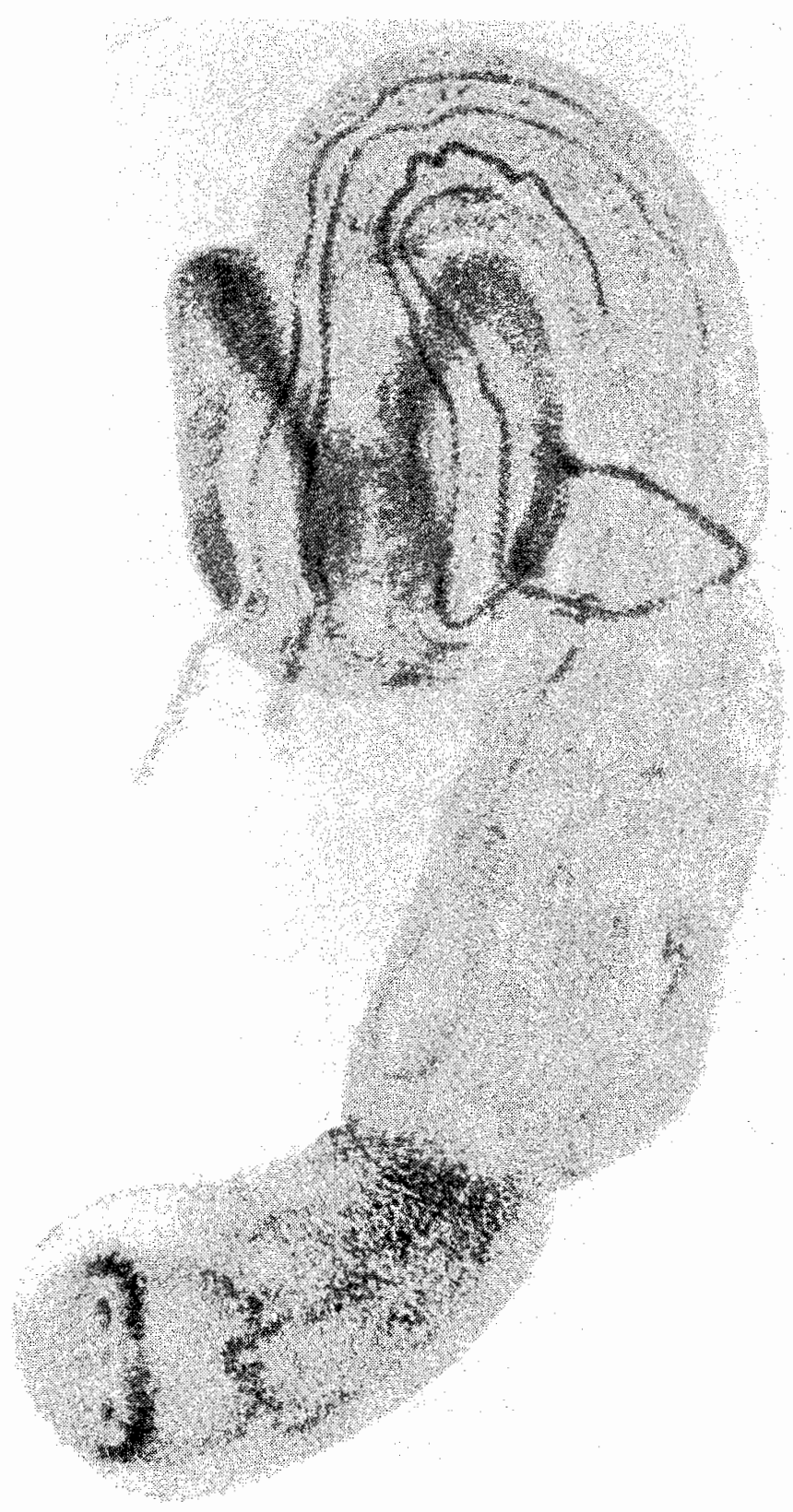

Fig. 3. Larwa of Lacistorhyncus tenuis isolated from the blastocystis

Phot. S.L. Kazubski 
Parasites of garfish Belone belone (L.) and dimension of invasion

\begin{tabular}{|c|c|c|c|c|c|c|c|c|}
\hline $\begin{array}{c}\text { Year } \\
\text { of } \\
\text { study }\end{array}$ & Date & $\begin{array}{l}\text { No. of } \\
\text { fish } \\
\text { exam. }\end{array}$ & $\begin{array}{l}\text { Lacistho- } \\
\text { rhynchus } \\
\text { tenuis }\end{array}$ & $\begin{array}{l}\text { Anisakis } \\
\text { simplex }\end{array}$ & $\begin{array}{l}\text { Thynnascaris } \\
\text { adunca }\end{array}$ & $\begin{array}{l}\text { Neochinor- } \\
\text { hynchus } \\
\text { rutili }\end{array}$ & $\begin{array}{c}\text { Pomphor- } \\
\text { hynchus } \\
\text { laevis }\end{array}$ & $\begin{array}{l}\text { Echinor- } \\
\text { hynchus } \\
\text { gadi }\end{array}$ \\
\hline \multirow{3}{*}{1978} & Sep. 9 & 20 & - & & - & - & 5 & 5 \\
\hline & Sep. 28 & 14 & - & & - & - & 21.4 & 21.4 \\
\hline & Oct. 12 & 26 & - & & - & - & & 15.3 \\
\hline \multirow{2}{*}{1979} & June 28 & 15 & & & & & & \\
\hline & Sep. 13 & 11 & - & & - & - & 9.09 & - \\
\hline \multirow[t]{2}{*}{1980} & June 10 & 17 & & 58 & - & - & - & - \\
\hline & Total & 103 & & & & & & \\
\hline
\end{tabular}

explanation: inci ence (\%)

intensity 


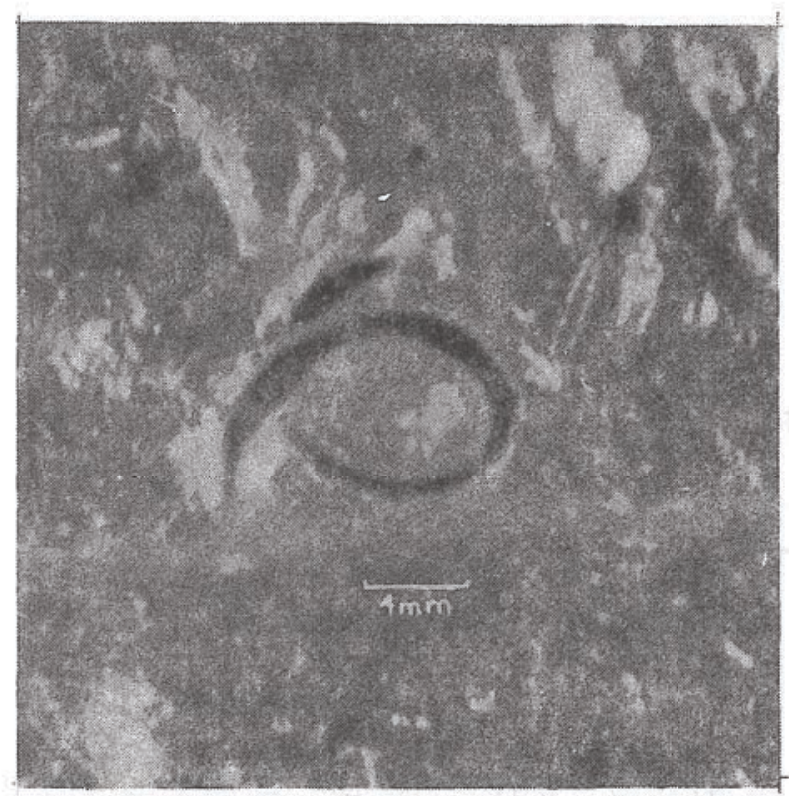

Fig. 4. Anisakis simplex larva III-st. under the skin of garfish.

been examined, but as one may judge from the results reported by Rokicki (1975), they are free of $A$. simplex. That author examined $21 \mathrm{~A}$. tobianus and $39 \mathrm{H}$. lanceolatus individuals from the Gulf of Gdańsk and found no trace of the presence of the $A$. simplex larvae.

Within the study period, the garfish was very often found to be infested with the Anisakis larvae (cf. Table 1). The invasion incidence in the samples ranged within $9.1-66.6 \%$, while the invasion intensity was as low as $1-3$ parasites per fish. It is interesting to note that even during the invasion of such a low intensity, the parasites were found living in muscle and just under the skin. In the latter case they are well visible from the outside as melanine is aggregated in the skin around the places of nematode settlement under it, resulting in a nematode outline being clearly seen from the outside (Fig. 4).

Thus the two parasitic species: $L$. tenuis and $A$. simplex, can be used as biological indicators evidencing the garfish migrations. The garfish, infested with parasites native for fully marine waters such as the North Sea, migrates all over the Baltic to reach as far as the Finnish coasts, which is shown by the A. simplex larvae invasion in the garfish examined by Fagerholm (1976). 


\section{CONCLUSIONS}

1. The parasites of the Pomeranian Bay garfish consist of the Atlantic species such as Lacistorhynchus tenuis (van Beneden) plerocercus and Anisakis simplex (Rud.) stage 3 larvae as well as of the Baltic species, typical of brackish and fresh waters: Thynnascaris adunca (Rud.), Neoechinorhynchus rutili (Müller), Pomphorhynchus laevis (Zoega in Müller), and Echinorhynchus gadi Zoega in Müller.

2. L. tenuis and $A$. simplex are biological indicators evidencing the remote origin of the garfish that spawns in the Pomeranian Bay.

3. The $L$. tenuis and $A$. simplex larvae have been for the first time recorded in the garfish in the coastal zone of the Polish part of the Baltic Sea.

\section{REFERENCES}

Demel $K_{\circ}$, 1937: Some words on the occurrence and reproduction of garfish (Belone acus Risso) in our sea. - Biul. St. Morsk. w Helu 1, Nr. 2, Warszawa.

Demel Ko, 1948: Orphie (Belone acus Risso) la reproduction et le development. - Ann. Biol.III Copenhague.

Dollfus $\mathbb{R}_{\text {-Ph. }}$, 1942: Études critiques sur les Tétrarhynques du Muséum de Paris. - Arch. Mus. Nat. Hist. Nat. VI Série T. XIX.

Engelbrecht Ho, 1958: Untersuchungen über den Parasitenbefall der Nutzfische im Greifswalder Bodden und Kleinen Haff. - Z. Fischer., VIII N.F., H. 7/8.

Fagerholm H.-P., 1976: Fish nematodes from brackish- and freshwater fishes in Finland. - Norw.J. Zool. 24 (4) [Abstract ].

Grabda J., 1974: The dynamics of the nematode larvae Anisakis simplex (Rud.) invasion in the South-Western Baltic herring (Clupea harengus L.). - Acta ichthyol. et piscat. 4.

Grabda J., (Red.), 1971: [Catalogue of Parasitic Fauna in Poland. II, Parasites of Cyclostomates and Fishes]. PWN Warszawa-Wrocław.

Grabda J., 1976: The occurrence of Anisakis nematode larvae in Baltic cod (Gadus morhua callarias L.) and the dynamics of their invasion. - Acta ichthyol. et piscat. 6.

Jensen A.J.C., 1937: Seasonal guests in transition area. ' $L$ Rapport et Proc. Verb. des Reun., CII, Copenhague.

Kompowski A., 1965 a: The investigations on the garfish (Belone belone L.) from the Puck Bay.- Prace M.I.R. 13, Ser. A.

Kompowski A., 1965 b: The biological caracteristic of garfish catches in Puck Bay in 1964. - Zesz: Nauk. WSR w Olsztynie, 20, Nr. 429.

MacKenzie K., 1976: Parasites as biological tags for herring. - Norw. J. Zool 24 (4) [Abstract].

Prost M., 1967: Comparison of some species of fishes from the Mediterranean, Adriatic and Baltic seas. - Acta parasitol. pol., XIV, 32.

Robinson E.S., 1959: Records of Cestodes from Marine Fishes of New Zealand. - Trans. of the Royal Society of New Zealand. 86, Part 1.

Rokicki J., 1975: Helminth fauna of the Gdańsk Bay (Baltic Sea) - Acta parasit. pol., XXIII, 2.

Rynkiewicz Jo, 1970: The parasite fauna of gar-fish - Belone belone (L.) from Puck Bay. - Acta ichthyol. et piscat., 1 .

Wegener C., 1909: Die Ektoparasiten der Fische Ostpreussens. - Schr. phys. ökon. Ges. 50. Königs berg. 
Jadwiga Grabda

\section{PARAZYTOFAUNA BELONY BELONE BELONE (L.) Z ZATOKI POMORSKIEJ POZUDNIOWEGO BAETYKU I JEJ POCHODZENIE}

Streszczenie

W latach 1978-1980 zbadano 103 belony Zatoki Pomorskiej Południowego Bałtyku. Znaleziono 6 gatunków pasoży tów. Wśród nich wyróżniono 2 gatunki atlantyckie, zawleczone przez belonę do Bałtyku prawdopodobnie z Morza Północnego. Są to: plerocercus tasiemca czteroryjkowca (Tetrarhynchida) Lacistorhynchus tenuis (van Beneden, 1858) i larwa III stadium nicienia Anisakis simplex (Rud., 1809). Oba te gatunki pasożytów nie mają w Południowym Bałtyku pełnego zestawu żywicielskiego i nie mog̨ się rozmnażać.

Drugą grupę pasożytów stanowią gatunki wód słonawych i słodkich, jak Thynnascaris adunca (Rud., 1802), Neoechinorhynchus rutili (Müller, 17\%8), Pomphorhynchus laevis (Zoega in Müller, 1776) i Echinorhynchus gadi Zoega in Müller, 1776. Są to pasożyty pospolite w Bałtyku u wielu gatunków ryb. Belona zaraża się nimi na tarliskach przyórzeżnych, gdzie żeruje przy dnie w okresach między poszczególnymi etapami tarła.

Pasożyty atlantyckie świadczą o dalekich wędrówkach tarłowych belony, która przy południowych wybrzezach Bałtyku pojawia się tylko w okresie wiosenno-letnim na tarło a na zimę prawdopodobnie odpływa z powrotem na zachód.

\section{Я. Грабда}

ПАРАЗИТОФАУНА И ПРОИСХОЖД ННИЕ ОБЫЕНОВЕННОГО САРГАНА (ВЕLОNE BELONE( $\left(L_{\circ}\right)$ ) ИЗ ПОМОРСКОЙ БУХТЫ ЮНОЙ БАЛТАИИ

\section{$P$ e 3 o 4 e}

В 1978-1980 годы исследовалд 103 экземпяра, обынновенвого саргава пз По-

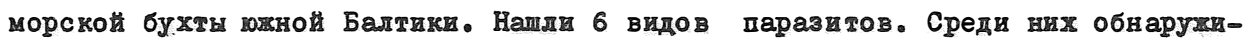
ли 2 атлантически вида; притащены обыквовевны сарганом в Балтику вероятво из Северного моря. Это: шлеродеркоид дестоды Tetrarhynchida -Lacistorhynchus tenuis(van Beneden, 1858) личинка III сталии нематоды Anisakis simplex (Rud.,1809). Эти виды паразитов ве имеют в кохой Балтике полного состава хозяев и поэтому не могут размножатся. Вторую групп паразитов составляют виды паразитов солоноватых вод а также пресных вод: Thynnascaris adunca: (Rud., 1802), Neoechinorhynchus rutili (MUller, 1780), Pomphorhynchus laevis (Zoega in Muller, 1776) , Echinorhynchus gadi Zoega in Muller, 1776.

Эти паразиты обиденные Б Балтике. Из находят у. многих видов рыб. Обыяно-

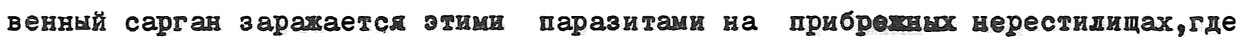




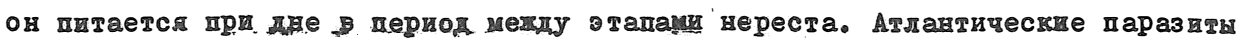

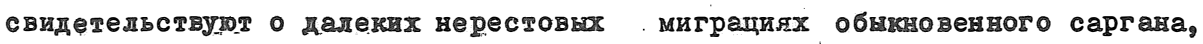

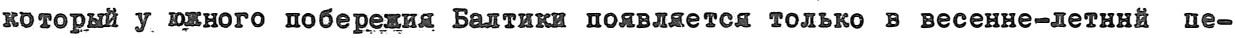

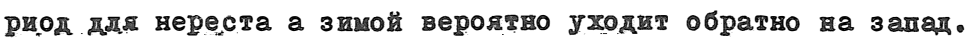

negeron: dr Józef Domagaza

Received: 1 IX 1980

Address:

Dr Jadwiga Grabda

Instytut Ichtiologii

71-550 Szczecin, ul. Kazimierza Królewicza 4

Polska (Poland) 